\title{
Effect of feeding betaine hydrochloride and bypass fat supplement on feed intake, milk yield and physiological parameters in lactating buffaloes during heat stress
}

\author{
SS Shankhpal, CR Waghela, PL Sherasia, AK Srivastava and V Sridhar \\ Received: 29 December 2018 / Accepted: 29 March 2019 / Published online: 22 June 2019 \\ (C) Indian Dairy Association (India) 2019
}

\begin{abstract}
Present study examined the effect of feeding betaine hydrochloride (BH) and bypass fat (BF) in 24 early lactating buffaloes during May to July, 2018 in Nadiad district of Gujarat state. Buffaloes (30-35 days in milk) yielding 10-12 kg milk/d were divided into three groups of eight each based on milk yield, fat $\%$ and stage of lactation. Buffaloes in $\mathrm{T}_{1}$ group (control) were fed basal ration. In addition to basal ration, buffaloes in $T_{2}$ group were fed daily $30 \mathrm{~g} \mathrm{BH}+100 \mathrm{~g}$ buffer; while buffaloes in $\mathrm{T}_{3}$ group were fed daily $30 \mathrm{~g} \mathrm{BH}+100 \mathrm{~g}$ buffer $+100 \mathrm{~g} \mathrm{BF}$ for 60 days. Average thermal humidity index was 80.10 at $14: 00 \mathrm{hr}$ during the trial period. Study revealed that $\mathrm{DMI}$ improved $(\mathrm{P}=0.011)$ in $\mathrm{T}_{3}$ group as compared to control. Non-significant difference in milk yield was observed among the groups; however, reduction in milk yield was lower in $\mathrm{T}_{2} \& \mathrm{~T}_{3}$ groups, as compared to control. Milk fat improved by $3.2 \%$ and $6.2 \%(\mathrm{P}=0.002)$ in $\mathrm{T}_{2}$ and $\mathrm{T}_{3}$ groups, respectively. Rectal temperature $\left(102.8,102.7^{2}\right.$ vs $\left.103.6^{\circ} \mathrm{F}\right)$, respiration rate $(46.0,45.1 \mathrm{vs} 60.1 \mathrm{breath} / \mathrm{min}$.) and pulse rate $(61.2,58.5$ vs 72.9 pulse/min.) at 14:00 hr were significantly $(\mathrm{P}<0.01)$ lower in buffaloes under $T_{2}$ and $T_{3}$ group as compared to $T_{1}$ group. Average net daily income was increased by Rs. 36.02 and 47.43 in $T_{2}$ and $T_{3}$ group, respectively as compared to control.
\end{abstract}

Keywords: Betaine, Buffalo, Bypass fat, Heat stress, Milk yield

SS Shankhpal, CR Waghela, PL Sherasia $(\varangle)$, AK Srivastava and V Sridhar

Animal Nutrition Group, National Dairy Development Board, Anand388 001, Gujarat, India

Email: pankajs@nddb.coop; Phone: (O) 02692-226270; (M) 097264 25891

\section{Introduction}

Due to ongoing climate change, the climate of India has become increasingly volatile over the past several decades. There is accumulating empirical evidence that the changing environmental conditions are already adversely impacting the livestock productivity. Higher temperatures along with altered precipitation are likely to result in the problem of heat stress in dairy animals leading to decreased production. West et al. (2013) and Babinszky et al. (2011) reported lower feed intake by $5-20 \%$ and reduction in milk yield by $10-40 \%$ in dairy cows due to heat stress. Loss of productivity in dairy animals in India during heat stress is a wellknown menace.

India possesses the world's largest livestock population having $57 \%$ of the world's buffalo (Bubalus bubalis) population. India is the largest milk producing country in the world and buffalo is the main milk producing animal contributing $>50 \%$ of the total milk production in India. Buffaloes are more vulnerable to heat stress at high ambient temperature due to less number of sweat glands and black coat colour leading to loss in their productive efficiency (Upadhyay et al. 2008). Exposure of buffaloes to the hot conditions causes a series of changes in the biological functions that include decrease in feed intake, efficiency and utilization, disturbances in metabolism of water, protein, energy and mineral balances, resulting in impairment of productive and reproductive efficiencies (Das et al. 2014).

Productivity loss during heat stress period can be minimized by providing strategic feed supplement. The provision of nutritional supplements to ameliorate the effects of heat stress in dairy animals is an attractive method and is potentially the fastest and easiest option for milk producers. One such supplement that has been recently studied is the organic amino acid derivative; dietary betaine (DiGiacomo et al. 2014). Physiologically, mammals utilise betaine as a methyl donor able to participate in protein and lipid metabolism, or when not catabolised, betaine can be used as an organic cellular osmoprotectant (Fernández et al. 1998; Huang et al. 2007). In addition, use of bypass fat supplement in early lactating animals increases the energy density of the diet enabling the animals to meet their energy and essential fatty acid requirements expressing their milk production potential (Sirohi 
et al. 2010). Keeping this in mind, present work has been undertaken to evaluate the effect of supplementing betaine hydrochloride and bypass fat on feed intake, milk yield and physiological parameters of lactating buffaloes during summer season.

\section{Materials and methods}

\section{Location, animals and dietary treatments}

Present study was undertaken during summer months $\left(18^{\text {th }}\right.$ May to $28^{\text {th }}$ July 2018) at an organized dairy farm of Dumral village in Nadiad district of Gujarat. Twenty-four early lactating (30-35 days in milk) buffaloes were divided into three groups of eight each, based on milk yield (10-12 kg/d), fat (6.8-6.9\%) and stage of lactation (2-4 lactations). Buffaloes in control group $\left(\mathrm{T}_{1}\right)$ were fed basal diet comprising of 6-7 $\mathrm{kg}$ concentrate, $20 \mathrm{~kg}$ green fodder and $4.0 \mathrm{~kg}$ dry fodder (NRC, 2001). In addition to basal diet, animals in $\mathrm{T}_{2}$ group were supplemented daily $30 \mathrm{~g} \mathrm{BH}$ and $100 \mathrm{~g}$ buffer; and buffaloes in $\mathrm{T}_{3}$ group were supplemented daily $30 \mathrm{~g}$ $\mathrm{BH}, 100 \mathrm{~g}$ buffer and $100 \mathrm{~g} \mathrm{BF}$ for 60 days. Buffer contained $49 \mathrm{~g}$ sodium bicarbonate, $21 \mathrm{~g}$ magnesium oxide and $30 \mathrm{~g}$ potassium chloride. Bypass fat was procured from M/s. Berg Schmidt Indian Pvt ltd, Pune.

\section{Temperature and humidity}

Ambient temperature and relative humidity were recorded twice daily at 09:00 and 14:00 hrs in buffalo shed during the trial period. Daily maximum and minimum ambient temperatures were recorded and calculated thermal humidity index (THI) as per the equation $\mathrm{THI}=0.72\left(\mathrm{~T}_{\mathrm{db}}+\mathrm{T}_{\mathrm{wb}}\right)+40.6$; where $\mathrm{T}_{\mathrm{db}}$ is the temperature of the dry bulb and $\mathrm{T}_{\mathrm{wb}}$ is the temperature of the wet bulb (NRC 1971).

\section{Feed, fodder and milk analyses}

The chemical composition of feeds and fodder offered to buffaloes during the trial period was carried out as per AOAC (2005). All buffaloes were hand milked twice daily (06:00 and 18:00 hrs) and individual milk yield was recorded. The milk samples were collected at weekly intervals from individual buffaloes during both milking time. After proper mixing, pooled milk samples $(100-150 \mathrm{ml})$ from each buffalo were collected and analysed for fat, SNF, protein and lactose contents by an automatic milk analyzer. Average feeding cost and realization receipt from the sale of milk was calculated based on the current market prices.

\section{Physiological parameters}

Rectal temperature, respiration rate and pulse rate were recorded twice daily at 09:00 and 14:00 hrs for 2 consecutive days in every week. The rectal temperature $\left({ }^{\circ} \mathrm{F}\right)$ was recorded using a digital thermometer by inserting 3 inches in the rectum for about $2 \mathrm{~min}$. The respiration rate per minute was recorded by counting the movement of flank, i.e. one outward and inward movement considered as one respiration. The pulse rate per minute was counted by palpating coccygeal artery.

\section{Statistical analysis}

Data were analysed using one-way ANOVA with SPSS package programme (SPSS 9.00 software for Windows, SPSS Inc., Chicago, IL) as per Snedecor and Cochran (1994). When F-test was significant $(\mathrm{P}<0.05)$, Turkey's test was utilized to compare significant difference $(\mathrm{P}<0.05)$ among the groups.

\section{Results and discussion}

\section{Chemical composition}

Analysis of feeds and fodder offered to buffaloes in all three groups is given in Table 1. Bypass fat (Bergafat) contained 99\% total fat (min.). Fatty acid composition contained about $77.22 \%$ palmitic acid $\left(\mathrm{C}_{16: 0}\right), 1.21 \%$ myristic acid $\left(\mathrm{C}_{14: 0}\right), 5.14 \%$ stearic acid $\left(\mathrm{C}_{18: 0}\right), 12.49 \%$ olic acid $\left(\mathrm{C}_{18: \ln 9 \mathrm{c}}\right), 2.56 \%$ linoleic acid $\left(\mathrm{C}_{18: 2 \mathrm{n} 6 \mathrm{c}}\right)$ and 0.35 arachidic acid $\left(\mathrm{C}_{20: 0}\right)$.

\section{Weather conditions}

The weather conditions during the experimental period $\left(18^{\text {th }}\right.$ May to $28^{\text {th }}$ July, 2018) were typically hot. The average ambient air temperature at 9.00 and $14.00 \mathrm{hrs}$ during the experimental period was $32.03 \pm 0.40^{\circ} \mathrm{C}$ and $36.13 \pm 0.96^{\circ} \mathrm{C}$, respectively. Whereas, average humidity at 9.00 and $14.00 \mathrm{hrs}$ was $70.90 \pm 1.40 \%$ and $60.71 \pm 2.44 \%$, re-spectively. The average calculated THI was $70.22 \pm 0.65$ and $80.10 \pm 1.07$ units at 9.00 and $14.00 \mathrm{hrs}$, respectively during the trial period. The maximum THI was recorded at initial period ( 0 week) of experiment (85.24).

\section{Dry matter intake}

It is well known that dairy animal reduces its feed intake during the heat stress as a thermoregulation effort to prevent an excessive increase in body temperature via decreasing its heat production. West et al. (2013) reported that feed intake reduced by $5-20 \%$ in dairy cows due to heat stress.

In our study, initial dry matter intake (DMI) in all three groups were similar $(14.05,14.19$ and $14.16 ; \mathrm{P}=0.231)$. However, during the trial period, DMI reduced by $1.86,1.71$ and $1.42 \mathrm{~kg}$ in $\mathrm{T}_{1}, \mathrm{~T}_{2}$ and $\mathrm{T}_{3}$ groups, respectively (Table 2 ). Despite reduction in all three groups, $\mathrm{DMI}$ in $\mathrm{T}_{3}$ group was significantly higher $(\mathrm{P}=0.011)$ by $4.51 \%$ as compared to control group, which indicates that the heat stress has less effect on DMI in $\mathrm{T}_{3}$ group as compared to control (Figure. 1). Non-significant improvement in DMI was observed in $\mathrm{T}_{2}$ group as compared to $\mathrm{T}_{1}$ group. Marai and Habeeb (2010) reported that the reduction in DMI is the most important effect of heat stress in tropical and sub-tropical conditions. Increased heat load decreases nutrient uptake in almost all species and in case of cattle, the nutrient uptake decreases upto 
Fig. 1 Inter-relationship between THI and DMI

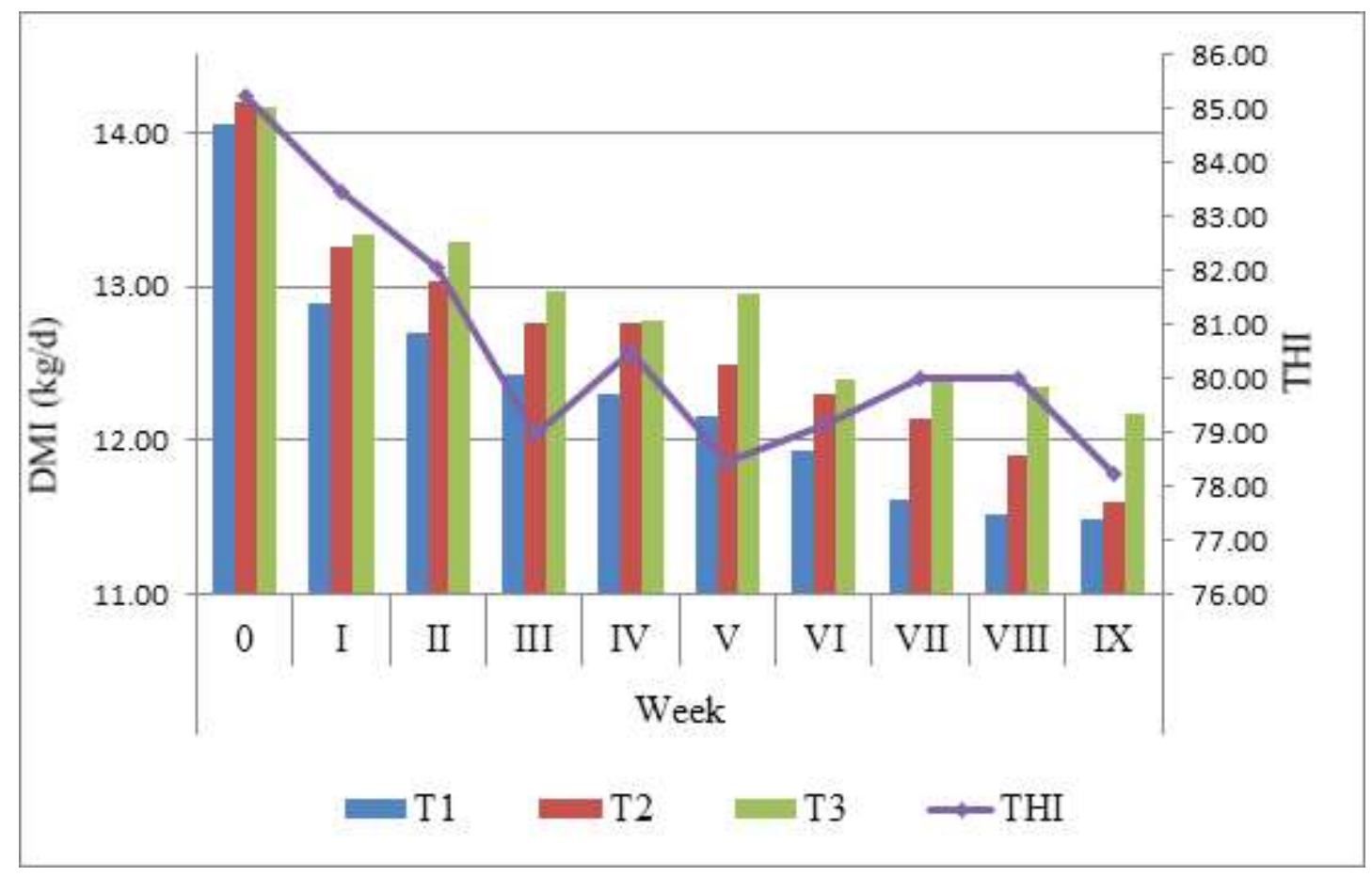

Table 1 Chemical composition of feeds and fodder ( $\%$ DM basis)

\begin{tabular}{lllllll}
\hline Feed ingredients & CP & EE & CF & AIA & Ca & P \\
\hline Concentrate mixture & 19.87 & 4.28 & 9.07 & 1.20 & 0.86 & 0.76 \\
Wheat straw & 3.12 & 1.64 & 39.10 & 6.26 & 0.74 & 0.10 \\
Maize green fodder & 7.42 & 2.29 & 28.92 & 6.58 & 0.66 & 0.27 \\
\hline
\end{tabular}

about $30 \%$ of dry matter intake (Rhoads et al. 2013; Wheelock et al. 2010). A decrease in the dry matter intake in dairy cattle was found on exposure to heat stress (Rhoads et al. 2009). High environmental temperature reported to reduce feed intake in Friesian heifers (Smith et al. 2013).

\section{Milk yield}

As the lactation progress, milk production decline in all animals, but reduction in milk yield was less in treatment groups as compared to control group; may be due to supplementation of $\mathrm{BH}$ and $\mathrm{BF}$ in buffaloes. Milk yield was higher $(\mathrm{P}=0.334)$ by 5.69 and $6.73 \%$ in $\mathrm{T}_{2}$ and $\mathrm{T}_{3}$ group, respectively as compared to $\mathrm{T}_{1}$ group. The average milk fat in $\mathrm{T}_{1}, \mathrm{~T}_{2}$ and $\mathrm{T}_{3}$ was $6.93,7.15$ and $7.36 \%$, respectively, which showed that the $\mathrm{BH}$ and $\mathrm{BF}$ supplementation in concentrate mixture of lactating buffaloes $\left(\mathrm{T}_{2}\right.$ and $\left.\mathrm{T}_{3}\right)$ increased $(\mathrm{P}=0.002)$ fat content of milk as compared to control group $\left(\mathrm{T}_{1}\right)$.

Marai et al. (2009) recorded lower milk yield in buffaloes during summer than spring and winter seasons and decline in milk yield as a direct result of high environmental temperature. Wang et al. (2010) reported that by adding 100 or $150 \mathrm{~g}$ of anhydrous betaine significantly improved milk yield and fat during the early lactation of Holstein dairy cows. Zhang et al. (2014) studied that the addition of up to 15 and $20 \mathrm{~g}$ /day betaine caused milk yield to increase by 29.16 and $28.87 v s .27 .70 \mathrm{~kg} / \mathrm{d}$ (control), respectively. Bouraoui et al. (2002) found that daily THI is negatively correlated with milk yield and observed that increasing THI value from 68 to 78 decrease milk production by $21 \%$ and DMI by $9.6 \%$. Aggarwal and Singh, (2006) also reported that milk yield decreases by 0.41 $\mathrm{kg} / \mathrm{cow} / \mathrm{d}$ for each point increase in the THI values above 69.0. In our study also, we observed weekly inter-relationship between THI and daily milk yield of buffaloes during the whole trial period (Figure 2).

\section{Economics}

Daily feeding cost of ration was Rs. $209.59,223.30$ and 234.71 in $\mathrm{T}_{1}, \mathrm{~T}_{2}$ and $\mathrm{T}_{3}$ groups, respectively which was significantly higher $(\mathrm{P}=0.001)$ in $\mathrm{T}_{2}$ and $\mathrm{T}_{3}$ groups as compared to $\mathrm{T}_{1}$ group. Higher feeding cost in experimental group was mainly due to the higher DMI and addition of supplemental cost. However, daily realizable receipt (Rs./head) from the sale of milk was higher by 9.12 and $13.30 \%(\mathrm{P}=0.037)$ in $\mathrm{T}_{2}$ and $\mathrm{T}_{3}$ groups, respectively as compared to control group. Cost benefit ratio (net income per unit feeding cost) was found to be higher in $T_{2}(1.67)$ and $T_{3}(1.63)$ groups, as compared to $T_{1}(1.60)$ group. Thus, net daily income of farmer increased by Rs. 36.02 and 47.43 per animal after supplementation 
Fig. 2 Inter-relationship between THI and milk yield

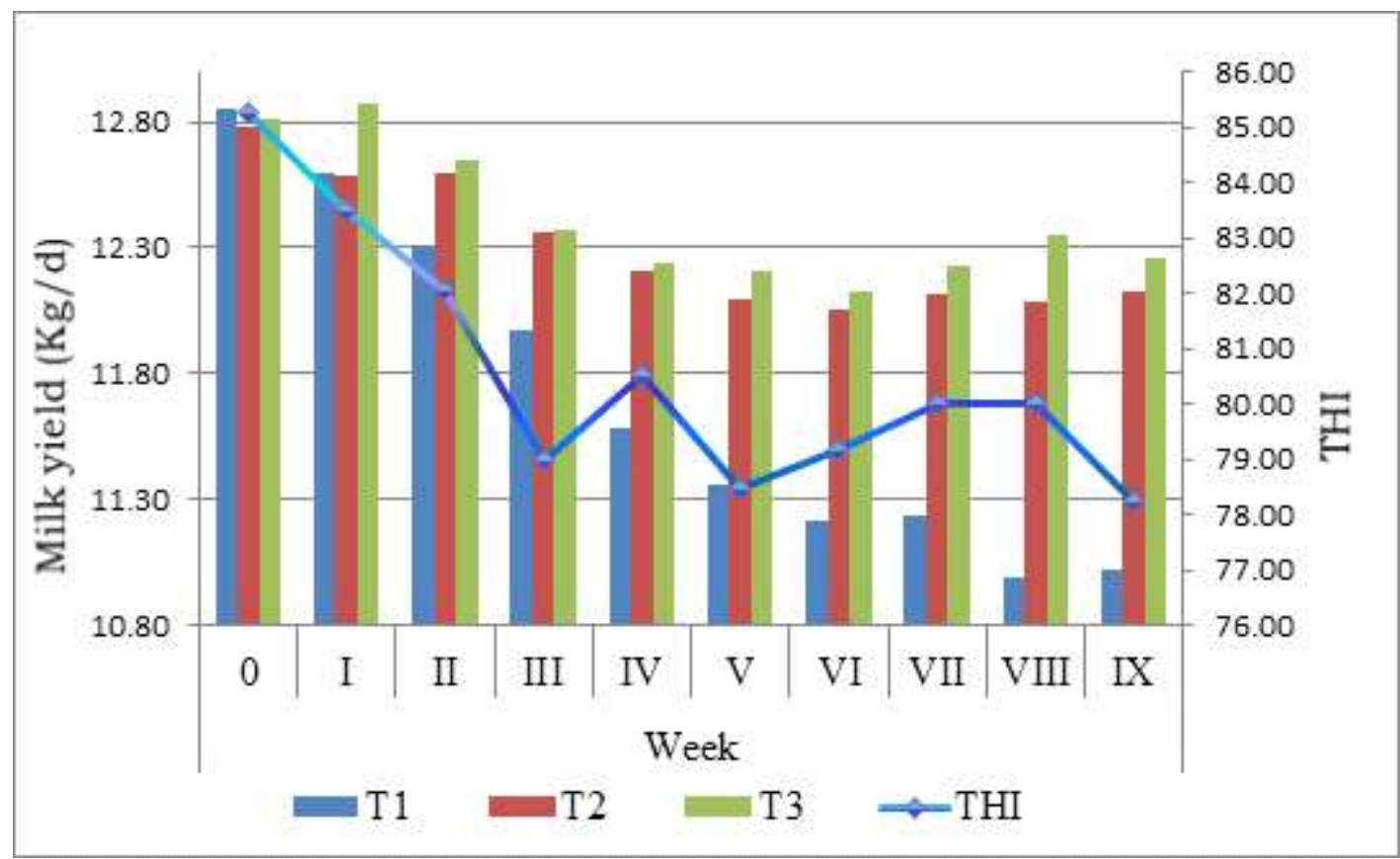

Table 2 Effect of feeding betaine and bypass fat on feed intake, milk yield and economics

\begin{tabular}{|c|c|c|c|c|c|}
\hline Parameters & $\mathrm{T}_{1}$ & $\mathrm{~T}_{2}$ & $\mathrm{~T}_{3}$ & SEM & $\mathrm{P}$ value \\
\hline \multicolumn{6}{|l|}{ Feed intake } \\
\hline Initial DMI (kg/d) & 14.05 & 14.19 & 14.16 & 0.09 & 0.231 \\
\hline DMI $(\mathrm{kg} / \mathrm{d})$ after 60 days of trial & $12.19^{\mathrm{a}}$ & $12.48^{\mathrm{ab}}$ & $12.74^{\mathrm{b}}$ & 0.09 & 0.011 \\
\hline Initial milk yield (kg/d) & 12.85 & 12.78 & 12.81 & 0.22 & 0.326 \\
\hline Milk yield $(\mathrm{kg} / \mathrm{d})$ after 60 days & 11.59 & 12.25 & 12.37 & 0.23 & 0.334 \\
\hline Protein $(\%)$ & 3.40 & 3.42 & 3.45 & 0.01 & 0.222 \\
\hline Lactose $(\%)$ & 5.24 & 5.29 & 5.30 & 0.02 & 0.439 \\
\hline \multicolumn{6}{|l|}{ Economics } \\
\hline Daily feeding cost (Rs./head) & $209.59^{a}$ & $223.30^{\mathrm{b}}$ & $234.71^{\mathrm{c}}$ & 2.50 & 0.001 \\
\hline Realizable receipt from sale of milk (Rs./head/d) & $545.39^{a}$ & $595.13^{\mathrm{b}}$ & $617.95^{\mathrm{b}}$ & 11.77 & 0.037 \\
\hline
\end{tabular}

${ }^{a b c}$ Means bearing different superscripts in a row differ significantly $(P<0.05)$

of $\mathrm{BH}$ alone and along with $\mathrm{BF}$ in $\mathrm{T}_{2}$ and $\mathrm{T}_{3}$ group over $\mathrm{T}_{1}$ group, respectively.

\section{Physiological parameters}

The rectal temperature and respiration rate is recognized as an important measure of physiological status as well as ideal indicator for assessment of stress in dairy animals. Rectal temperature is generally considered to be a useful measure of body temperature and changes in rectal temperature indicates changes of a similar magnitude in deep body temperature (Ganaie et al. 2013). In our study, supplementation of BH, buffer and BF helped to reduce heat stress in buffaloes. Average rectal temperature $\left(103.6,102.8,102.7^{\circ} \mathrm{F} ; \mathrm{P}=0.01\right)$, respiration rate $(60.1$,
46.0, 45.1 per min; $\mathrm{P}=0.01)$ and pulse rate $(72.9,61.2,58.5$ per min; $\mathrm{P}=0.01$ ) were significantly lower at $14: 00 \mathrm{hr}$ in $\mathrm{T}_{2}$ and $\mathrm{T}_{3}$ groups as compared to control group (Table 3). Physiological parameters indicate that the buffaloes in control group were more prone to heat stress as compared to supplemental groups. Gaughan et al. (2005) suggested that the addition of exogenous osmolytes significantly reduce the rectal temperature, and increases the feed intake and heat endurance of buffaloes during heat stress. The results of our study showed that the rectal temperature significantly declined with $\mathrm{BH}$ and $\mathrm{BH}$ with $\mathrm{BF}$ supplemented groups. This trend might be related to the function of $\mathrm{BH}$, which helps animals to alleviate heat stress. 
Table 3 Physiological parameters of buffaloes

\begin{tabular}{llllllc}
\hline Attribute & Time $(\mathrm{hrs})$ & $\mathrm{T}_{1}$ & $\mathrm{~T}_{2}$ & $\mathrm{~T}_{3}$ & SEM & P value \\
Rectal & 9.00 & 101.5 & 101.3 & 101.6 & 0.08 & 0.398 \\
temperature $\left({ }^{\circ} \mathrm{F}\right)$ & 14.00 & $103.6^{\mathrm{b}}$ & $102.8^{\mathrm{a}}$ & $102.7^{\mathrm{a}}$ & 0.13 & 0.01 \\
Respiration rate & 9.00 & 44.1 & 42.0 & 40.9 & 0.67 & 0.133 \\
(breath/min.) & 14.00 & $60.1^{\mathrm{b}}$ & $46.0^{\mathrm{a}}$ & $45.1^{\mathrm{a}}$ & 1.60 & 0.01 \\
Pulse rate & 9.00 & 56.7 & 55.0 & 55.0 & 0.63 & 0.346 \\
(Pulse/min.) & 14.00 & $72.9^{\mathrm{b}}$ & $61.2^{\mathrm{a}}$ & $58.5^{\mathrm{a}}$ & 1.47 & 0.01 \\
\hline
\end{tabular}

${ }^{\text {abc }}$ Means bearing different superscripts in a row differ significantly $(P<0.05)$

\section{Conclusions}

Study indicates that supplementation of betaine hydrochloride, buffer and bypass fat in the ration of buffaloes improved dry matter intake, milk production as well as its component and also helped in maintaining crucial physiological parameters of buffaloes during hot condition. This supplementation during summer season increases the net daily income of farmer by $14 \%$ in comparison to control.

\section{Acknowledgements}

The financial assistance and facilities provided by the management of National Dairy Development Board, Anand for undertaking this study are gratefully acknowledged. Authors are also thankful to the owner of Sai Dairy Farm, Nadiad, where the study was undertaken.

\section{References}

Aggarwal A, Singh M (2006) Effect of water cooling on physiological responses, milk production and composition of Murrah buffaloes during hot-humid season. Indian J Dairy Sci 59 (4): 386-389

AOAC (2005) Official Methods of Analysis of the Association of Official Analytical Chemists. 18th edn. (AOAC International: Gaithersburg, Maryland, USA)

Babinszky L, Halas V, Verstegen MWA (2011) Impacts of climate change on animal production and quality of animal food products. In: Climate Change - Socioeconomic Effects. Kheradmand, H. (Ed.), In Tech (Europe). ISBN: 978-953-307-411-5

Bouraoui R, Lahmar M, Majdoub A, Djemali M, Belyea R (2002) The relationship of temperature-humidity index with milk production of dairy cows in a Mediterranean climate. Animal Research (51): 479-491

Das KS, Singh JK, Singh G, Upadhyay RC, Malik R, Oberoi PS (2014) Heat stress alleviation in lactating buffaloes: Effect on physiological response, metabolic hormone, milk production and composition. Indian J Anim Sci (84): 275-280

DiGiacomo K, Warner RD, Leury BJ, Gaughan CJB, Dunshea FR (2014) Dietary betaine supplementation has energy-sparing effects in feedlot cattle during summer, particularly in those without access to shade. Anim Prod Sci (54): 450-458

Fernández C, Gallego L, Lopez-Bote CJ (1998) Effect of betaine on fat content in growing lambs. Anim Feed Sci Tech (73): 329-338

Ganaie AH, Shanker G, Bumla NA, Ghasura RS, Mir NA(2013) Biochemical and physiological changes during thermal stress in bovines. J Vet Sci Technol (4): 126-131
Gaughan J, Cadogan D, Cawdell-Smith A, Roft I (2005) Improved heat tolerance of cattle by dietary supplementation with osmolytes. Asia Pac J Clin Nutr (14): 123

Huang QC, Xu ZR, Han XY, Li WF (2007) Effect of betaine on growth hormone pulsatile secretion and serum metabolites in finishing pigs. J Anim Physiol Anim Nutr (91): 85-90

Marai IFF, Haeeb AAM (2010) Buffalo's biological functions as affected by heat stress- A review. Livest Sci (127): 89-109

Marai IFM, Daader AH, Soliman AM, El Menshawy SMS (2009) Nongenetic factors affecting growth and reproduction traits of buffaloes under dry management housing (in sub-tropical environment) in Egypt. Livestock Research for Rural Development (21): 3

NRC (1971) A guide to environmental research on animals. National Academy of Sciences, Washington, DC

NRC (2001) Nutrient requirements of dairy cattle. 7th edn. National Academy Press, Washington DC

Rhoads ML, Rhoads RP, VanBaale MJ, Collier RJ, Sanders SR, Weber WJ, Crooker BA, Baumgard LH (2009) Effects of heat stress and plane of nutrition on lactating Holstein cows: I. Production, metabolism, and aspects of circulating somatotropin. J Dairy Sci (9):986- 997

Rhoads RP, Baumgard LH, Suagee JK, Sanders, SR (2013) Nutritional interventions to alleviate the negative consequences of heat stress. Adv Nutr (4): 267-276

Sirohi SK, Walli TK, Mohanta RK (2010) Supplementation effect of bypass fat on production performance of lactating crossbred cows. Indian J Anim Sci (80): 733-736

Smith DL, Smith T, Rude BJ, Ward SH (2013) Comparison of the effects of heat stress on milk and component yields and somatic cell score in Holstein and Jersey cows. J Dairy Sci (96): 3028-3033

Snedecor GW, Cochran WG (1994) Statistical Methods. 8th ed., Oxford and IBH Publishing Co. Pvt. Ltd., New Delhi, India.

Upadhyay RC, Singh SV, Ashutosh (2008) Impact of climate change on livestock. Indian Dairyman (60): 98-102

Wang C, Liu Q, Yang WZ, Wu J (2010) Effects of betaine supplementation on rumen fermentation, lactation performance, feed digestibilities and plasma characteristics in dairy cows. J Agr Sci (148): 487-495

West JW, Mullinix BG, Bernard JK (2013) Effects of hot, humid weather on milk temperature, dry matter intake, and milk yield of lactating dairy cows. J Dairy Sci (86): 232-242

Wheelock JB, Rhoads RP, Van Baale MJ, Sanders SR, Baumgard LH (2010) Effects of heat stress on energetic metabolism in lactating Holstein cows. J Dairy Sci (93): 644-655

Zhang L, Ying SJ, An WJ, Lian H, Zhou GB, Han ZY (2014) Effects of dietary betaine supplementation subjected to heat stress on milk performances and physiology indices in dairy cow. Genet Mol Res (13): 7577-7586 